Вісник Дніпропетровського університету. Серія: геологія, географія. 2016. 24 (1), 13-19.

Vìsnik Dnìpropetrovs'kogo unìversitetu. Serìa geologîa, geographìâ

Dnipropetrovsk University Bulletin. Series geology, geography. 2016, 24 (1), 13-19.

doi: $10.15421 / 111602$

http://geology-dnu.dp.ua

УДК 624.131.23; 624.131.537

\title{
Оцінювання стійкості схилів річкових долин Полтавського лесового плато
}

\author{
С. В. Біда, О. В. Куц \\ Полтавський національний технічний університет імені Юрія Кондратюка, Полтава, Украӥна, \\ e-mail: svbeda@rambler.ru
}

\begin{abstract}
Характерними особливостями рельєфу рівнинної частини України є річкові долини 3 високими та крутими схилами, складеними 3 поверхні лесовими грунтами. На схилах відбувається розвантаження грунтових вод із плато. Ці фактори створюють сприятливі умови для виникнення зсувних процесів на схилах. Розрахунки схилів із застосуванням характеристик міцності лесового грунту, отриманих за традиційними методиками не дозволяють правильно оцінити їх стійкість. Проведено оцінювання стійкості зсувного схилу із застосуванням характеристик структурної міцності грунту, отриманих з урахуванням впливу потоку грунтових вод. У результаті порівняння різних моделей грунту встановлено, що для моделювання зсувних процесів найбільш вдалою є модель пружно-пластичного середовища. 3'ясовано, що реалізація такої моделі за допомогою методу скінченних елементів дозволяє врахувати усі особливості інженерногеологічних умов на схилі. У процесі розрахунків з'ясовано закономірності визначення розмірів розрахункової області. Оцінено вплив зменшення міцності лесових грунтів, що піддаються дії фільтраційного потоку грунтових вод, на стійкість схилу. Результатами розрахунків підтверджено, що внаслідок тривалої дії потоку лесові грунти повністю втрачають структурне зчеплення.
\end{abstract}

Ключові слова: схил, зсув, лесові трунти, характеристики міиності, коефіцієнт стійкості

\section{The evaluation of slopes stability of Poltava river valleys loess plateau}

\author{
S. V. Bida, O. V. Kuts \\ Yuri Kondratyuk Poltava National Technical University, Poltava, Ukraine, e-mail: svbeda@rambler.ru
}

The geological structure of the Poltava loessial plateau (tableland) is characteristic of Central Ukraine. From the plateau top there occur loessial soils that are underlain by water-resistant clay layers. On the overlying bed of clay layers there occurs the discharge of subsoil waters on river valley slopes. Flows of groundwater negatively affect loessial soils, compromising their strength. The with stand ability of slopes breaks and distortions happen. It is impossible to have the measure of the slope's durability using standard methods for determination of soil strength characterization. Due to the analysis of flow-induced effect of groundwater aquifers on loessial soils we have found out the mechanism of their load-yield curve change. The object of this work was to carry out the model analysis of stress-strain state of the slope of Poltava loessial plateau in order to estimate its durability taking into account these mechanisms. To simulate the soil we have chosen the model of elastoplastic structure, which gained widespread currency thanks to easy handling and quite high accuracy of calculation. The implementation of such model by means of finite-element technique allows creating the computational domain of desired configuration and size, to take into account the peculiarities of soil bedding and to give every engineering-geological element its strength characteristics. So as to size up the with stand ability, we have simulated stress-strain state of the slope, situated in Poltava-town, in the off-street Instytutskyi proriz, using the plane elastic problem. The computational domain of the slope is presented as a polygon, which upper edge repeats the profile of the slope. We have chosen the size of calculation zone in such a way, so that interface conditions would not influence the development of landslides. After the creation the calculation area is divided by the finite element mesh. The choice of the mesh density is made based on the analysis of design model and development zone of plastic deformations. Infill drilling is made if necessary and in the places, where the strain-stress state has to be estimated with maximum precision. The calculation data have given an opportunity to evaluate the with stand ability of the slope with consideration for the stress reduction of loessial soils and to receive the pattern of soil slip development. The formation of slicken sided surface, moving direction and bulk up of the soil were completely on a par with soil slip development in the real situation. We have ascertained, that with stand ability coefficient in such a case is 0,84 , while in the case of defining the with stand ability of the slope using with stand ability characteristics, received by means of standard techniques, the with stand ability coefficient is 1,54 . Thus, we have confirmed the correctness of with stand ability characterization, received with the help of structural strength method, taking into account the influence of the seepage flow of groundwater aquifers.

Keywords: slopes, landslide, loess soils, the characteristics of strength, the coefficient of stability

Dniprop. Univer. Bull. Ser.: geology, geography. 2016. 24 (1) 
Вступ. Рівнинна частина України являє собою систему декількох плато, розділених долинами річок. У свою чергу, великі плато поділяються на менші внаслідок діяльності малих річок, джерел та тимчасових потоків води. На схилах річок, що досягають у висоту декількох десятків, а то й сотень метрів, утворюються ідеальні умови для появи зсувів. Одна 3 територій, $з$ характерною для Центральної України геологічною будовою (Demchishin, 1992; Velikodniy, 2006), - Полтавське лесове плато. 3 поверхні плато залягають четвертинні леси та лесовані суглинки 3 прошарками похованого грунту потужністю до 20 м. Підстилаються вони четвертинними червоно-бурими глинами твердої і напівтвердої консистенції, які є водотривом для грунтових вод. Особливістю інженерно-геологічної будови Полтавського лесового плато $€$ наявність улоговин у покрівлі водотривкого шару, який розміщується на глибині близько $16-18$ м від поверхні землі. Улоговини мають різноманітні розміри, форму та походження (Bida, 2011), але характерна їх особливість - це утворення в них потоків грунтових вод, що розвантажуються з плато на схили річкових долин, ярів та балок. Вплив таких грунтових потоків на стан грунтів проявляється у зменшенні їх міцності, що особливо характерно для лесів (Bida, 2011; Velikodniy, 2011; Yagolnik, 2011). Відбувається це внаслідок того, що за впливу грунтових вод лесові грунти переходять у текучий стан, у їх товщі виникають процеси суфозії, що спричинює виникнення зсувів.

У результаті вивчення зміни характеристик лесового грунту за впливу потоку грунтових вод (Bida, 2015; Kuts, 2015) були виявлені закономірності зміни критичних дотичних напружень від тривалості дії фільтраційного потоку та зроблено висновок про повну втрату лесовим грунтом структурної міцності. Мета роботи: використовуючи результати досліджень зміни характеристик міцності грунту за впливу потоку грунтових вод, провести моделювання напруженодеформованого стану схилу Полтавського лесового плато для визначення його стійкості.

Матеріал і методи досліджень. Через складність та різноманіття природних процесів, які відбуваються у грунтовій товщі, під час розробки розрахункових моделей грунту виникає необхідність у спрощенні і схематизації явищ, що розглядаються, та властивостей грунтів. Розроблені на наш час моделі грунтів мають свої переваги і недоліки, тому, проводячи розрахунки, необхідно вибрати модель, яка б, з одного боку, 3 необхідною точністю описувала поведінку масиву грунту (наприклад, зсувного схилу), а з іншого - не створювала додаткових труднощів у iï реалізації.
Найточнішою моделлю, напевно, була б модель дискретного середовища, оскільки грунт складається 3 окремих частинок, але впровадження цієї моделі навіть зараз важко реалізувати, зважаючи на іiі складність. Тому широкого розвитку набули методи розрахунків, в основу яких покладено модель суцільного (квазіоднорідного) середовища. Такий підхід дозволяе використати досягнення теорії пружності, теорії пластичності та інші.

Застосування теорії пружності започаткували П. О. Мінаєв та М. П. Пузиревський і розвинув М. М. Герсєванов. Враховуючи, що грунт не $є$ пружним тілом, М. М. Герсєванов (Gersevanov, 1948; Polshyn, 1948) рекомендував використовувати термін «теорія лінійнодеформівного тіла». Завдяки простоті і доступності ця теорія отримала широке розповсюдження, однак через неврахування пластичних деформацій область використання іï обмежена.

За наявності граничного стану в усіх точках розрахункової області необхідно скористатися моделлю теорії граничної рівноваги, яка за своєю суттю $є$ повною протилежністю моделі лінійнодеформівного тіла. Найсуттєвіший недолік теорії граничної рівноваги -iї бездеформативність, оскільки вона не враховує переміщення, що відбуваються у грунті до його переходу у граничний стан.

Аналізуючи залежності «навантаження-осідання», М. М. Герсєванов виділив три фази і дав характеристику кожній із них. У рамках лінійно-деформованого середовища можливе описання лише першої фази. Для інших двох необхідно використовувати рішення нелінійної механіки грунтів. Для цього можливе використання двох підходів - нелінійно-пружного і пружно-пластичного.

Нелінійно-пружний підхід грунтується на використанні нелінійних залежностей між напруженнями і деформаціями. Однак із застосуванням такого підходу до розв'язання задач області пластичних деформацій не виділяються, а самі деформації враховуються спільно $з$ пружними.

Пружно-пластичні моделі описують пружні і пластичні деформації різними фізичними залежностями. Пластичні деформації залежать не лише від рівня досягнутого напруженого стану, а й від усієї траєкторії навантаження. Розв' язання пружно-пластичних задач реалізується за допомогою покрокового навантаження грунтових масивів згідно з черговістю прикладання та зміни зовнішнього навантаження.

Модель пружно-пластичного середовища дозволяє відобразити всю історію накопичення пластичних деформацій, в тому числі поведінку грунту до досягнення ним граничного стану. Така модель найбільш 
вдала для розв’язання багатьох задач, у тому числі визначення стійкості схилів чи укосів. Однак більш широке розповсюдження отримав спрощений варіант такої моделі у вигляді ідеально-пружно-пластичного середовища. Це дозволяє розв’язувати низку так званих змішаних задач, коли у масиві одночасно існують зони дограничного і граничного напруженого стану грунту.

Дана модель реалізована в програмному комплексі «Plaxis». Теоретичну основу розрахунку складає математичне описання грунту як суцільного ізотропного середовища, яке моделюється відповідно до теорії пластичної течії. Процедурну основу складає метод початкових напружень (МПН) разом із методом скінченних елементів (MCE). На користь вибору такої геомеханічної моделі свідчить те, що фізичні рівняння, які використовуються, перевірені на практиці та містять механічні характеристики грунту, що визначаються за стандартними методиками.

Для оцінювання стійкості зсувних схилів із застосуванням механічних характеристик лесових грунтів, отриманих з урахуванням впливу фільтраційного потоку грунтових вод, проведено моделювання напружено-деформованого стану схилу, розміщеного у м. Полтава по пров. Інститутський проріз.

У геоморфологічному відношенні територія належить до Полтавського лесового плато і розташована на схилі правого берега р. Ворскла. Абсолютні позначки поверхні землі схилу змінюються в межах від 150,0 до 85,0 м. Зсувні процеси відбуваються у нижній частині схилу в інтервалі позначок 130,0 $-95,0 \mathrm{M}$.

Інженерно-геологічні умови схилу представлені глинистими відкладами четвертинної формації, що підстилаються строкатими глинами неогену морського походження. 3 поверхні плато складене лесовими відкладами, товща яких досягає 15 м. Потужність червоно-бурих глин становить $20-25$ м, а неогенових - 10 - 15 м. Під глинами залягають піски полтавської та харківської світ. Схил із поверхні перекритий насипними та делювіально-пролювіальними відкладами з високим рівнем грунтової води в середній та нижній частині схилу. Делювіально-пролювіальні відклади в основному представлені перевідкладеними грунтами лесових та лесоподібних грунтів із включеннями різноманітного походження.

У результаті вивчення архівних та фондових матеріалів, проведення інженерно-геологічних вишукувань, у межах досліджуваної території виділено такі інженерно-геологічні елементи (IГЕ) з поверхні плато:
IГЕ-1 - насипні грунти - суміш грунтоворослинного шару, суглинків, будівельного сміття, потужністю 0,8 - 1,0 м;

ІГЕ-2 - суглинки жовто-коричневі, карбонатні, лесові, посадочні, напівтверді, потужністю 2,4 - 2,8 м;

IГЕ-3 - суглинки палево-жовті, карбонатні, лесові, посадочні, тверді, потужністю 2,3 - 3,1 м;

IГЕ-4 - суглинки коричнево-бурі, карбонатні, лесові, посадочні, напівтверді, потужністю 4,3 - 6,3 м;

IГЕ-5 - суглинки буро-жовті, карбонатні, лесові, текучопластичні, потужністю $3,1-3,8$ м;

IГЕ-6 - глини коричнево-бурі, червоно-бурі, карбонатні, лесові, ненабухаючі, напівтверді, потужністю до 23,0 м;

IГЕ-7 - суглинки лесові, жовто-сірі, шаруваті, карбонатні, від тугопластичних до текучопластичних, потужністю до 4,0 м;

IГЕ-7а - суглинки бурувато-жовті, карбонатні, шаруваті, від м'якопластичних до текучопластичних, потужністю до 3,0 м;

ІГЕ-8 - глини сірі, світло-сірі, напівтверді, карбонатні, шаруваті, слабонабухаючі;

ІГЕ-9 - піски жовто-сірі, кварцові, пилуваті, однорідні, маловологі, середньої щільності потужністю до 5,0 м.

Інженерно-геологічний розріз схилу показано на рисунку 1.

Характеристики різних інженерно-геологічних елементів наведено у таблицях 1, 2 .

Гідрогеологічні умови території характеризуються наявністю постійного безнапірного водоносного горизонту грунтового типу, водовмісними породами служать четвертинні відклади. Функції водотривкого шару виконують грунти IГЕ-6 та IГЕ-7. Живлення горизонту інфільтраційне, посилене витоками з водоносних комунікацій. Розвантаження водоносного горизонту відбувається по схилу і фільтрується в піски полтавської світи. Однак із часом у пісках відбувається процес кольматації (замулення) і верхній горизонт пісків набуває властивостей водотриву. Такий процес спричинює подальше зволоження грунтів, розміщених нижче по схилу. Через деякий час замочений стан стає характерним для поверхневих відкладів по всьому схилу. На момент проведення інженерно-геологічних вишукувань рівень грунтових вод на плато перебував на глибині близько 12 м від поверхні землі. Однак на території розвитку зсуву глибина грунтових вод становила $0,5-1,5$ м, а в деяких місцях грунтові води виходили на поверхню схилу. 


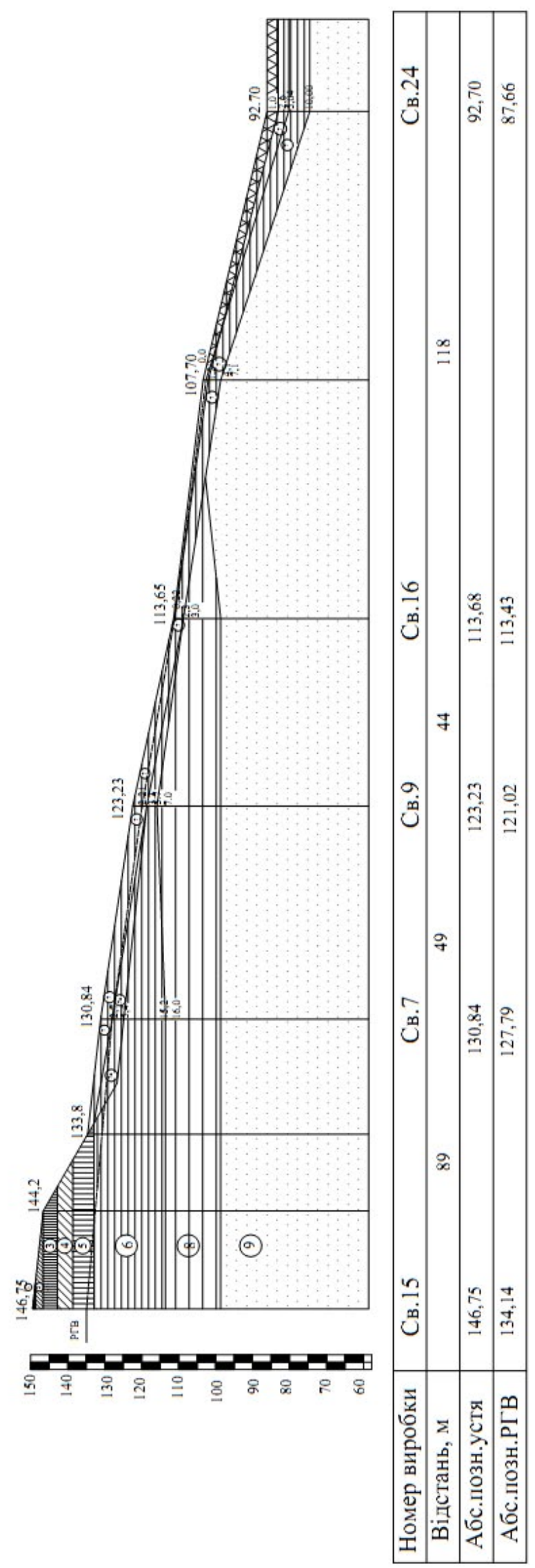

Рис. 1. Інженерно-геологічний розріз схилу по провулку Інститутський проріз
Характеристики грунтів були визначені за результатами інженерно-геологічних вишукувань, проведених організацією «Полтаваінжрозбуд». Розрахунки стійкості схилу, проведені із застосуванням цих характеристик, показали, що схил перебуває у стійкому стані, оскільки його коефіцієнт стійкості $(\mathrm{kst}=1,54)$ значно перевищував 1. Насправді ж, на схилі вже відбувалися зсувні процеси.

Після аналізу розміщення покрівлі водотривкого шару було виявлено улоговину, в межах якої режим грунтових вод значно відрізняється від звичайного. Тривалий вплив потоку грунтових вод спричинив зменшення характеристик міцності, тому у процесі моделювання інженерно-геологічним елементам, розміщеним вище водотриву в межах дії потоку грунтових вод, надавались значення механічних характеристик, визначених за методикою структурного зчеплення (Bida, 2015; Kuts, 2015). Структурне зчеплення лесових грунтів в улоговині приймалось рівним нулю.

Для оцінювання НДС грунтового масиву розглядалась плоска задача, а розрахункова схема подана у вигляді прямокутника на площині та розміщується у правій частині декартової системи координат. Розміри розрахункової області встановлювалися таким чином:

- нижня горизонтальна межа повинна міститися у шарі, що не має особливих властивостей та перебуває у стійкому стані; за глибину розрахункової області приймається межа, розміщена нижче шарів грунту, що зазнають впливу зсувних процесів;

- бічні вертикальні межі приймаються на достатній відстані від зони визначення НДС і місця концентрації напружень. Ширина розрахункової області повинна забезпечувати розміщення схилу по усій його довжині для визначення положення осередку виникнення зсувних процесів. Відстань від бічних меж до схилу повинна вибиратись 3 умови максимального зменшення впливу з урахуванням заборони горизонтальних переміщень;

- верхня межа приймається на рівні поверхні землі і повторює рельєф схилу;

- для проведення контрольних розрахунків можливе врахування прогнозованого підняття рівня грунтових вод.

Розрахункова область плоскої задачі представляється прямокутником, або багатокутником, верхня грань якого повторює профіль схилу, на площині, та розміщується у правій декартовій системі координат. Після утворення розрахункової зони вона розбивається на окремі елементи, форма, розміри $\mathrm{i}$ положення яких відповідають інженерно-геологічній будові схилу. Оскільки розв'язання задачі прийня- 
Фізичні характеристики грунтів на зсувному схилі у м. Полтава по провулку Інститутський проріз

\begin{tabular}{|c|c|c|c|c|c|c|c|c|c|c|}
\hline \multirow{2}{*}{\multicolumn{2}{|c|}{ Характеристики }} & \multicolumn{9}{|c|}{ Номер ІГЕ } \\
\hline & & 2 & 3 & 4 & 5 & 6 & 7 & $7 \mathrm{a}$ & 8 & 9 \\
\hline \multicolumn{2}{|c|}{ Вологість на межі текучості } & 0,36 & 0,29 & 0,36 & 0,29 & 0,46 & 0,31 & 0,31 & 0,67 & - \\
\hline \multicolumn{2}{|c|}{ Вологість на межі пластичності } & 0,21 & 0,19 & 0,21 & 0,19 & 0,24 & 0,20 & 0,19 & 0,31 & - \\
\hline \multicolumn{2}{|c|}{ Число пластичності } & 0,15 & 0,10 & 0,15 & 0,10 & 0,22 & 0,11 & 0,12 & 0,36 & - \\
\hline \multicolumn{2}{|c|}{ Природна вологість } & 0,24 & 0,18 & 0,23 & 0,27 & 0,27 & 0,25 & 0,28 & 0,36 & 0,07 \\
\hline \multicolumn{2}{|c|}{ Вологість при повному водонасиченні } & 0,40 & 0,37 & 0,39 & 0,36 & 0,30 & 0,38 & 0,32 & 0,37 & 0,25 \\
\hline \multicolumn{2}{|c|}{ Показник текучості } & 0,20 & $-0,10$ & 0,13 & 0,80 & 0,14 & 0,45 & 0,75 & 0,14 & - \\
\hline \multicolumn{2}{|c|}{ Показник текучості водонасиченого грунту } & 1,26 & 1,84 & 1,19 & 1,65 & 0,29 & 1,64 & 1,07 & 0,16 & - \\
\hline \multicolumn{2}{|c|}{ Коефіцієнт водонасичення } & 0,60 & 0,48 & 0,59 & 0,76 & 0,89 & 0,66 & 0,88 & 0,98 & 0,28 \\
\hline \multicolumn{2}{|c|}{ Питома вага частинок грунту, кН/м³ } & 26,59 & 26,49 & 26,59 & 26,4 & 26,7 & 26,5 & 26,5 & 26,8 & 26,1 \\
\hline \multicolumn{2}{|c|}{ Питома вага грунтів, кН/м³ } & 15,99 & 15,70 & 16,09 & 17,3 & 18,7 & 16,5 & 18,4 & 18,4 & 16,9 \\
\hline \multicolumn{2}{|c|}{ Питома вага сухих грунтів, кН/м ${ }^{3}$} & 12,90 & 13,31 & 13,08 & 13,62 & 14,72 & 13,2 & 14,38 & 13,53 & 15,79 \\
\hline \multicolumn{2}{|c|}{ Питома вага водонасичених грунтів, кН/м³ } & 18,05 & 18,28 & 18,16 & 18,46 & 19,21 & 18,22 & 18,95 & 18,48 & 19,74 \\
\hline \multicolumn{2}{|c|}{ Питома вага зважених у воді грунтів } & 8,05 & 8,28 & 8,16 & 8,46 & & 8,22 & 8,95 & & 9,74 \\
\hline \multicolumn{2}{|c|}{ Коефіцієнт пористості } & 1,06 & 0,99 & 1,03 & 0,94 & 0,81 & 1,01 & 0,84 & 0,98 & 0,65 \\
\hline \multicolumn{2}{|c|}{ Відносна деформація набухання } & & & & & 0,01 & & & 0,048 & \\
\hline \multirow{6}{*}{$\begin{array}{c}\text { Відносна } \\
\text { просадочність за } \\
\text { тисків у МПа }\end{array}$} & 0,05 & 0,009 & 0,002 & 0,001 & & & & & & \\
\hline & 0,10 & 0,021 & 0,006 & 0,004 & & & & & & \\
\hline & 0,15 & 0,030 & 0,011 & 0,09 & & & & & & \\
\hline & 0,20 & 0,036 & 0,015 & 0,090 & & & & & & \\
\hline & 0,25 & 0,043 & 0,024 & 0,013 & & & & & & \\
\hline & 0,30 & 0,049 & 0,034 & 0,017 & & & & & & \\
\hline
\end{tabular}

Механічні характеристики грунтів на зсувному схилі у м. Полтава по провулку Інститутський проріз

\begin{tabular}{|c|c|c|c|c|c|c|c|c|c|}
\hline \multirow{2}{*}{ Характеристики } & \multicolumn{9}{|c|}{ Номер ІГЕ } \\
\cline { 2 - 29 } & 2 & 3 & 4 & 5 & 6 & 7 & $7 \mathrm{a}$ & 8 & 9 \\
\hline Питоме зчеплення грунту, с, кПа & 15 & 8 & 16 & 11 & 23 & 20 & 18 & 32 & 4 \\
\hline Кут внутрішнього тертя, $\varphi$, град & 25 & 26 & 26 & 25 & 24 & 18 & 17 & 11 & 30 \\
\hline Модуль деформації, Е, МПа & 2,0 & 4,5 & 7 & 9 & 13 & 7,5 & 10 & 11 & 18 \\
\hline
\end{tabular}

те в плоскій постановці, то положення інженерногеологічних елементів відповідає їх нашаруванню по тальвегу улоговини.

Положення меж ІГЕ приймається відповідно до результатів інженерно-геологічних вишукувань. Профіль схилу під час моделювання був прийнятий таким, яким він був до розвитку зсувних процесів за результатами архівних даних інженерно-геодезичних вишукувань.

Розрахункову зону зсувного схилу по провулку Інститутський проріз показано на рисунку 2, а. Товща масиву представлена дев' ятьма різними шарами грунту з відповідними характеристиками та властивостями. Геометрична модель має такі розміри: 300 м - по горизонталі та 66 м - по вертикалі. Подальші розрахунки показали правильність вибору розмірів розрахункової зони, оскільки зони пластичних деформацій не досягли ії меж і відповідали дійсному розвитку зсувних процесів.

Після створення розрахункової області відбувається формування сітки скінченних елементів, яка побудована на основі шестивузлових елементів (рис. 2, б).

Вибір густоти сітки проводиться на основі аналізу розрахункової схеми та зон розвитку пластичних деформацій. Збільшення густоти сітки відбувається переважно в місцях прогнозованої концентрації напружень (можливі зони зрушення, точки прикладання навантажень тощо). За необхідності згущення сітки проводиться локально в місцях, де напружено-дефор- 


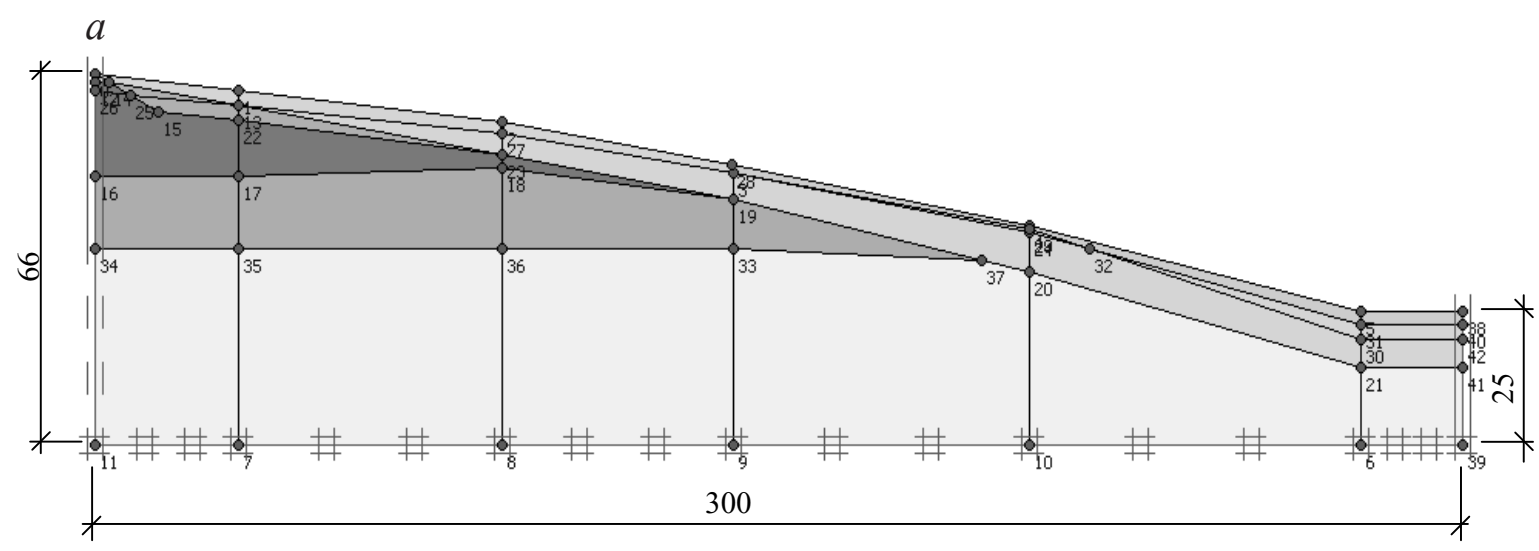

6
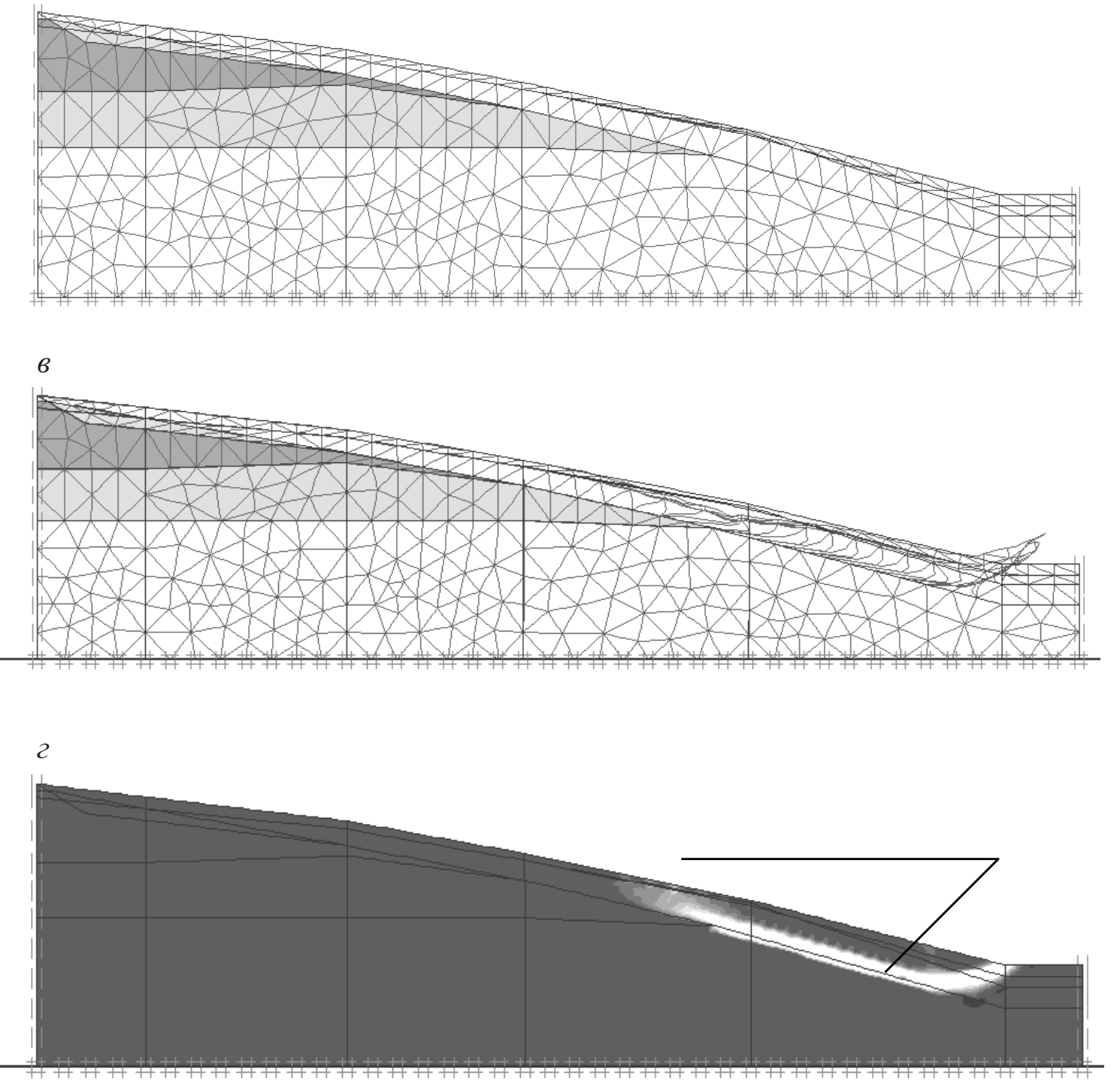

Рис. 2. Зсувний схил по провулку Інститутський проріз:

а - розрахункова зона;

б - сітка скінченних елементів;

в - деформована схема скінченних елементів;

г- утворення поверхні ковзання 
мований стан необхідно оцінити з більшою точністю.

Після створення моделі зсувного схилу на першому етапі визначаються початкові напруження від власної ваги грунту. Потім деформації «обнуляються», після чого методом $\varphi$ /c-reduction на другій фазі проводяться розрахунки стійкості схилу.

У результаті моделювання можна оцінити напружено-деформовний стан схилу шляхом аналізу розвитку як напружень так і деформацій.

На рисунку 2, в наведено схему розвитку зсувного процесу, отриману в результаті розв'язання задачі стійкості схилу. Формування зсувних мас повністю відповідає характеру розвитку зсуву на схилі. Однак найбільш цікавим є аналіз відносних деформацій, загальний вигляд яких показано на рисунку 2, г. На схемі чітко видно утворення поверхні ковзання, яка розміщена на межі корінних і покривних відкладів на схилі.

Висновки. Результати моделювання напруженодеформованого стану зсувного схилу по провулку Інститутський проріз із застосуванням характеристик міцності, отриманих за методикою структурного зчеплення $з$ урахуванням впливу фільтраційного потоку грунтових вод, дозволило отримати повну картину розвитку зсуву, яка відповідає дійсності. В розрахунках ураховано втрату лесовими грунтами структурного зчеплення. Встановлено, що коефіцієнт стійкості в цьому випадку становить 0,84 , тоді як у разі визначення стійкості схилу із застосуванням характеристик міцності, отриманих за стандартною методикою, коефіцієнт стійкості становить 1,54.

\section{Бібліографічні посилання}

Bida, S. V., 2011. Osoblyvosti zsuvnyh procesiv na chylah richkovyh dolyn [The landslide peculiarities on the slopes of river valleys]. Building construction, 75, 371-377 (in Ukrainian).

Bida, S. V., Kuts, O. V., 2015. Vplyv potokiv Iruntovih vod na zminu harakteristik miznocti lesovogo Iruntu [The influence of groundwater flow effect on changes of loess soils strength characteristics]. Visn. Dnipropetr. Univ. Ser. Geol. Geogr. 23(1), 3-16 (in Ukrainian), doi: 10.15421/111502.

Bida, S. V., Velikodniy, Yu. J., Yagolnik, A. M., 2009. Klasyfikacija ulogovyn Poltavs'kogo lesovogo plato [Classification basins Poltava loess plateau]. Economical resources materials, structures, buildings and constructions, 18, 548 - 553 (in Ukrainian).

Demchishin, M. G., 1992. Sovremennaja dinamika sklonov na territorii Ukrainy (inzhenerno-geologicheskie aspekty) [The current dynamics of the slopes on the territory of Ukraine (engineering-geotechnical aspects)]. Naukova Dumka, Kiev (in Russian).

Gersevanov, N. M., Polshyn, D. E., 1948. Teoreticheskie osnovy mehaniki gruntov $i$ ih prakticheskoe primenenie [Theoretical Fundamentals of mechanics soils and practical application]. Higher School, Moscow (in Russian).

Velikodniy, Y. I., 2006. Zahyst terytorij vid zsuviv: navchal'nyj posibnyk [Poltava Protecting areas of landslides: a tutorial]. LLC «Printing Center» Skaytek, Poltava (in Ukrainian).

Надійшла до редколегії 09.03.2016 